ACTA THERIOLOGICA

Vo1. 21, 17: 237-253, 1976

\title{
Abundance of Food Supply and Size of the Bank Vole's Home Range *
}

\author{
Roman ANDRZEJEWSKI \& Maria MAZURKIEWICZ
}

\begin{abstract}
Andrzejewski R. \& Mazurkiewicz M., 1976: Abundance of food supply and size of the bank vole's home range. Acta theriol., 21, 17: 237-253 [With 1 Table \& 6 Figs.].

Comparison was made of the size of the home range for males and females of different ages in a vole population, Clethrionomys glareolus (S chreber, 1780), both when the population lived on the natural food supply (1967), and when this supply was increased (1973) by constant supplementary feeding with oats. The population lived on a wooded island 4 ha in extent in a lake. Population parameters were recorded by means of the $C M R$ method, and the size of the home range was estimated by Wierzbowska's method (1972). The method used for estimating the size of the home range revealed an increase in the size of the home range in 1967 with successive captures of individuals, but in the year with supplementary feeding home ranges maintained a constant size with successive captures, and were smaller. Decrease in the size of the home range does not, however, compensate for increase in the degree to which the home ranges of individuals overlap in a population, as a result of increase in its density in 1973. It was shown in the discussion that the decrease in the size of the home range took place as a result of the limitation of great distance wandered by individuals from the centre of their activity. The size of the home range decreases from spring to autumn and the successive generations entering the population continue to have smaller home ranges than those of the older generations up to the autumn, both with the natural food supply and also when this supply was artificially increased.

[Inst. Ecol., Polish Acad. Sci., Dziekanów Leśny, 05-150 Łomianki Poland.]
\end{abstract}

\section{INTRODUCTION}

The static treatment of the size of the home range of various species of animals as their constant characteristic already belongs in a history of ecological research. The size of the home range is now considered dynamically, investigating the variations in size which depend on the internal situation in the population (e. g. density, sex structure, age structure, social organization etc.), and also on the features of the habitat in which the study population lives.

* Praca została wykonana w ramach problemu węzłowego $\mathrm{Nr}$ 09.1.7 koordynowanego przez Instytut Ekologii, Polskiej Akademii Nauk.

[237] 
It would seem that a particularly important influence is exerted on variations in the size of the home range by the food situation of the population. M c N a b (1963) and N i k i t in a \& M e r k o v a (1963) suggested that size of the home range depends on the possibility of satisfying the food requirements of the study species. This same species occurring in habitats with differing food supplies regulates the size of its home range according supply (Karaseva \& Ilyenko, 1957; Lavrova \& Andreeva, 1960; Saint Girons, 1960 ; Nikitina \& Merko$\mathrm{v}$ a, 1963; et al.).

Ecosystems with differing abundance of food supply also differ in respect of many other features which may exert an additional influence on the size of the home range, e. g. species composition of plants, their density, number of places in which to shelter, and also species composition of small mammals etc., which may present difficulties in comparing the effect of abundance of food supply on the size of the home range. Smith (1971) experimentally increased the food supply in a given ecosystem by laying out additional food for a population of Peromyscus polionotus (W a g n er, 1823) and found that this contributed to a reduction in the number of trapping sites visited by individuals in the study population.

The purpose of the present study was to attempt to define variations in the size of the home range by experimentally increasing the food supply of a population of Clethrionomys glareolus ( $\mathrm{S} \mathrm{hreber}, 1780$ ).

\section{STUDY AREA, METHODS, MATERIAL}

The studies were carried out on a bank vole population living on an island 4 ha in area, situated in a lake in northern Poland $\left(53^{\circ} 40^{\prime} \mathrm{N}, 21^{\circ} 35^{\prime} \mathrm{E}\right)$. This population has for many years formed the object of numerous studies by a group of researchers, and the tree stand covering the island has been described earlier ( $\mathrm{T} \mathrm{racz} \mathrm{y} \mathrm{k,} 1965$ et al.).

In order to define variations in the size of the home range taking place as a results of experimentally increasing food supply, from mid-September 1972 through the whole of 1973 the voles were supplied with oats in 159 wooden boxes with an entrance, distributed in grid $15 \times 15 \mathrm{~m}$, which covered the entire island. About $3 \mathrm{~kg}$ of oats were placed in each box and these were changed when the rodents had consumed about half.

Data on the population were collected from spring to autumn 1973 and compared with analogical data obtained in 1967 by the same method, except that the population lived on the natural food supply only.

Population parameters were recorded by means of the $C M R$ method, marking the rodents with individual numbers by toe-clipping. In both study years 5 series of trappings were made (i.e. in the second half of April, first half of June, second half of July, first half of September and second half of October), each series lasting for 7-14 days. The distribution of traps was always the same during the trapping periods and coincided with the places on which additional food was 
laid out in 1973. During the year when this was done 3 traps were placed inside the box with the oats during the first two trapping series, and 5 traps during the other series (the reason for the increase in the number of traps on a given site was the increase in population numbers). In 19673 traps were placed directly on the soil of the trapping site, and the animals caught in traps recorded twice daily at 7 o'clock in the morning and evening.

Andrzejewski et al. (1967) found that when the above method was used practically all voles currently inhabiting the island were caught in each trapping series, and it was thus possible to define population numbers by the general census of individuals method (Fig. 1). At the same time all individuals caught for the first time (i.e. marked) in a given trapping series are the youngest individuals in the population, which had left the nest during the period subsequent to the preceding trapping series. The groups of individuals thus distinguished were treated as generations born in the respective seasons of the year (Gliwicz,
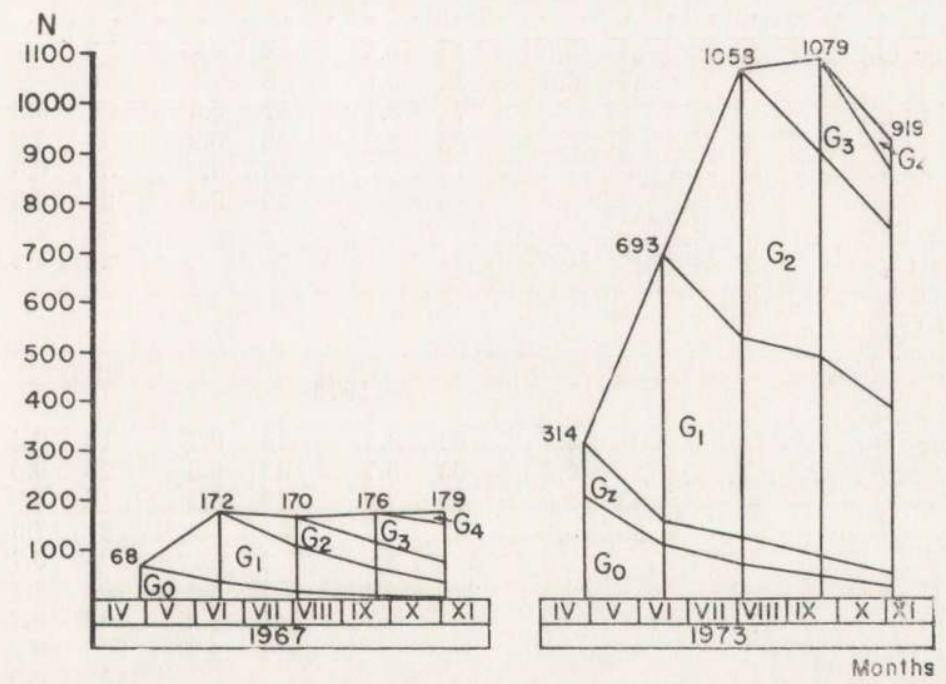

Fig. 1. Dynamics of population numbers in 1967 (after Petrusewicz et al., 1971) and in 1973.

$G_{0} \ldots G_{4}$ - different generations.

Andrzejewski, Bujalska \& Petrusewicz, 1968), and in this way the age and numbers of the various generations were defined in each trapping series and the age structure of the population obtained (Fig. 1).

In 1967 four generations born that year were distinguished, and the generation of adults born the previous year. In view of the fact that with the natural food supply reproduction does not begin in voles until April, the April trapping series recorded old adults only, as the young were still in the nest (Bujalska, Andrzewski \& Petrusewicz, 1968; Bujalska, 1970). Andrzejewski (1975) showed that in 1973, due to the voles being supplied with supplementary food, reproduction took place in winter, results in the appearance of a winter generation of voles caught for the first time in April, and consequently in 1973 it 
was possible to distinguish 5 generations of individuals born that year and also the generation of old adults.

Gliwicz (1970) found that the younger the given generation in the given age structure of the population, the lower was the average numbers of captures per individual in the study population, during the course of the different trapping series (i.e. real trappability). It proved possible, however, to obtain a sufficiently large number of captures for the majority of generations in successive trapping

Table 1

Numbers $(N)$, average number of captures $\left(n_{\mathrm{c}}\right)$ of study males and females of different generations.

\begin{tabular}{|c|c|c|c|c|c|c|c|c|c|c|c|}
\hline \multirow{2}{*}{ Generation } & \multirow[b]{2}{*}{ Sex } & \multicolumn{2}{|c|}{ April } & \multicolumn{2}{|c|}{ June } & \multicolumn{2}{|c|}{ July } & \multicolumn{2}{|c|}{ Sept. } & \multicolumn{2}{|c|}{ Oct. } \\
\hline & & $N$ & $\overline{n_{c}}$ & $N$ & $\overline{n_{c}}$ & $N$ & $n_{c}$ & $N$ & $n_{c}$ & $N$ & $n_{c}$ \\
\hline & \multicolumn{11}{|c|}{1967} \\
\hline Overwinter $G_{0}$ & M & 31 & 5.8 & 14 & 6.8 & 4 & - & 2 & - & - & - \\
\hline & $\mathrm{F}$ & 37 & 6.0 & 22 & 6.1 & 8 & - & 5 & - & 2 & \\
\hline Early spring $\mathrm{G}_{1}$ & M & & & 74 & 3.2 & 47 & 5.5 & 28 & 8.2 & 19 & 5.0 \\
\hline Early & $\begin{array}{c}\mathrm{F} \\
\mathrm{M}\end{array}$ & & & 62 & 2.9 & 43 & 5.9 & $\begin{array}{l}27 \\
30\end{array}$ & $\begin{array}{l}7.9 \\
6.8\end{array}$ & $\begin{array}{l}17 \\
23\end{array}$ & $\begin{array}{l}6.7 \\
4.4\end{array}$ \\
\hline summer $\mathrm{G}_{2}$ & $\begin{array}{l}\mathrm{M} \\
\mathrm{F}\end{array}$ & & & & & $\begin{array}{l}40 \\
28\end{array}$ & $\begin{array}{l}3.0 \\
2.5\end{array}$ & $\begin{array}{l}30 \\
21\end{array}$ & $\begin{array}{l}6.8 \\
7.8\end{array}$ & $\begin{array}{l}23 \\
15\end{array}$ & $\begin{array}{l}4.4 \\
5.3\end{array}$ \\
\hline Late & M & & & & & & & 38 & 2.8 & 18 & 3. \\
\hline summer $\mathrm{G}_{3}$ & F & & & & & & & 24 & 4.2 & 15 & 3. \\
\hline Early & M & & & & & & & & & 45 & 2.0 \\
\hline autumn $\mathrm{G}_{4}$ & $\mathrm{~F}$ & & & & & & & & & 25 & 2.2 \\
\hline
\end{tabular}

\begin{tabular}{|c|c|c|c|c|c|c|c|c|c|c|c|}
\hline \multirow{3}{*}{ Overwinter $\mathrm{G}_{0}$} & \multicolumn{11}{|c|}{1973} \\
\hline & M & 91 & 5.9 & 49 & 8.2 & 29 & 6.7 & 18 & 6.8 & 7 & - \\
\hline & $\mathrm{F}$ & 121 & 6.7 & 53 & 8.7 & 43 & 8.8 & 28 & 9.5 & 12 & 6.5 \\
\hline Winter $G_{z}$ & M & 43 & 3.0 & 19 & 7.2 & 19 & 5.4 & 14 & 6.9 & 8 & - \\
\hline & $\mathrm{F}$ & 59 & 3.4 & 32 & 8.8 & 30 & 7.2 & 21 & 7.5 & 18 & 6.9 \\
\hline Early & M & & & 263 & 3.9 & 214 & 6.2 & 204 & 5.7 & 165 & 6.2 \\
\hline spring $G_{1}$ & $\mathrm{~F}$ & & & 278 & 4.4 & 206 & 6.8 & 194 & 6.1 & 167 & 5.9 \\
\hline Early & M & & & & & 241 & 5.2 & 188 & 5.7 & 174 & 5.6 \\
\hline summer $G_{2}$ & $\mathrm{~F}$ & & & & & 276 & 4.8 & 225 & 6.0 & 187 & 6.2 \\
\hline Late & M & & & & & & & 106 & 4.9 & 66 & 7.8 \\
\hline summer $\mathrm{G}_{3}$ & $\mathrm{~F}$ & & & & & & & 81 & 4.2 & 51 & 6.3 \\
\hline Early & M & & & & & & & & & 24 & 6.0 \\
\hline autumn $\mathrm{G}_{4}$ & $\mathrm{~F}$ & & & & & & & & & 37 & 6.5 \\
\hline
\end{tabular}

series to permit an examination of the size of the home range (Table 1). A total number of 8,250 captures of 753 individuals was obtained in 1967, and 20,745 captures of 4,061 individuals in 1973.

\section{RESULTS}

The method chosen for assessing the average size of the home range from the number of trapping sites visited by the group of animals studied (Andrzejewski \& Wierzbowska, 1970; Wierzbowska \& Chelkowska, 1970; Wierzbowska, 1972) assumes that: (1) the home range of a rodent has distinct boundaries in a given period, beyond 
which the individual does not stray, and the trapping sites within the home range are visited with a similar degree of probability, (2) the measure of the home range is the number of trapping sites situated within its boundaries $(r)$ or the area measuring $r d^{2}$, where $d$-distance between trapping sites when arranged in a square grid, and (3) the shape of the home range is optional. With such assumptions the number of trapping sites revealed (sites on which the given individual was caught at least once) with a given number of captures of an individual is a function of the number of trapping sites which this individual could visit (i.e. the size of the home range). The appropriate tables for this function permit the convertion of the average number of sites revealed, with the given number of captures, into the size of the home range (W i e r z bow ska. 1972).

The great advantage of this method, which resulted in its being chosen for this study, is the possibility of using a short trapping series of an individual (only two captures are necessary) if the numbers of the group for which the size of the home range is to be calculated is sufficiently large. Although these assumptions are frequently not met, it is possible to draw conclusions as to changes taking place in the relative size of the home range and to compare these values in different groups of animals (Andrzejewski \& Wierzbowska, 1970; Wierzb ow ska, 1972).

The first step in analysis of the material was to check whether the estimated average size of the home range of females and males of the vole generations distinguished has a constant value as the successive captures of the animals take place, within the range of second to tenth capture in a given trapping series. Only those cases where the number of individuals of a given generation were caught at least 10 times were used for analysis. In the other cases analysis was made of changes in the size of the home range only up to that capture at which the above condition was still met

The analysis showed that in 1967 the size of the home range for males increased with successive captures of individuals in all generations and in all trapping series, except for the generation born in the spring $\left(G_{1}\right)$ and captured in the September series, and the generation born in the autumn $\left(G_{4}\right)$ and captured in the October series. A characteristic of these two cases is the relatively high value of the size of the home range when it is estimated at the second capture, and then the abrupt decrease in this value with the third capture and a further gradual increase with further captures. In 1973, however, the size of the home range of males was maintained on a similar level during all subsequent captures, in all generations and all trapping series (Fig. 2). 

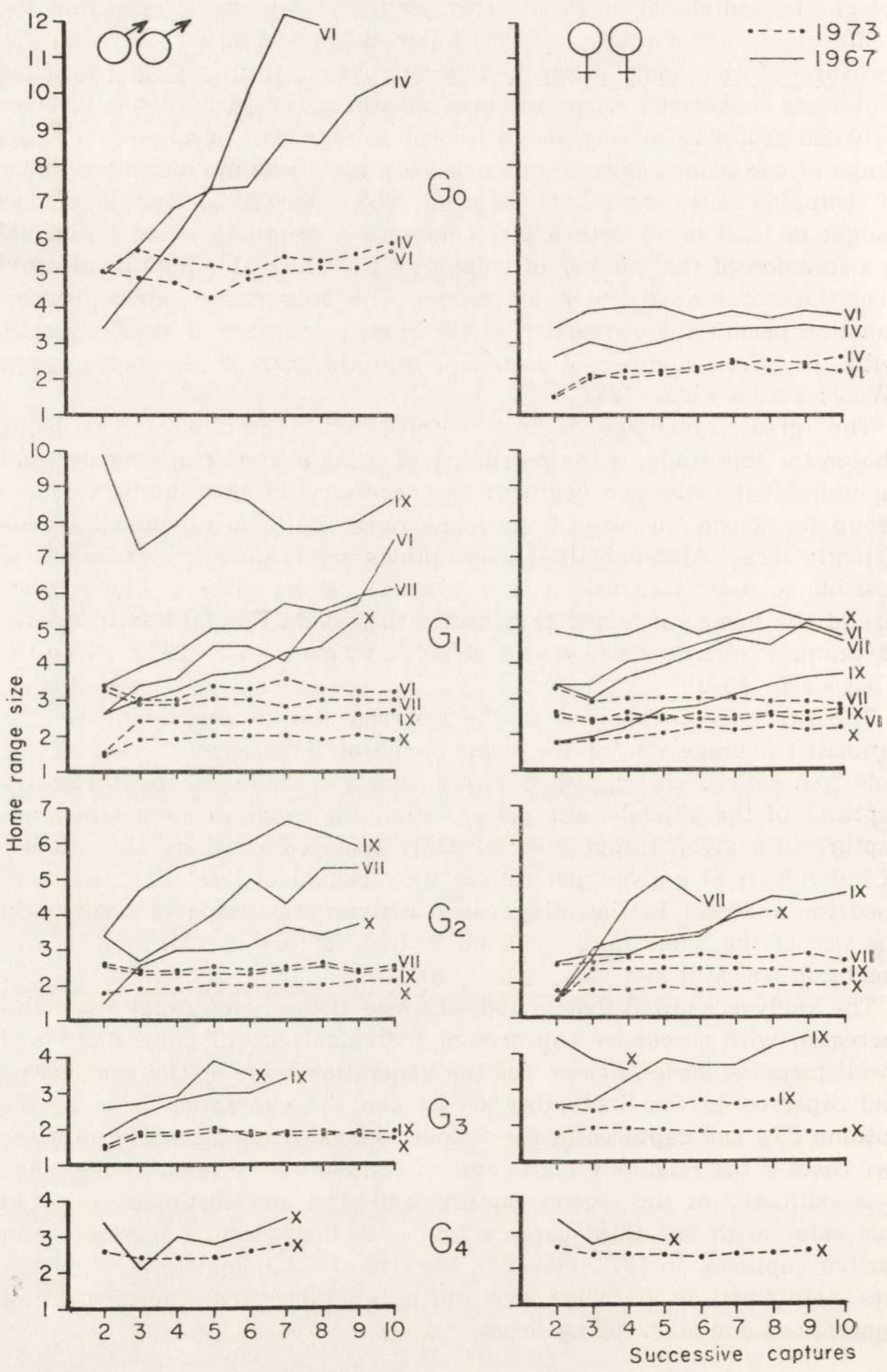
In 1967 the size of the home range of females increased with successive captures, in the spring generation in all trapping series except for October, in the early summer generation $\left(G_{2}\right)$ in all trapping series and in the late summer generation $\left(G_{3}\right)$ in the September series. The size of the home range for females of the old adult generation $\left(G_{0}\right)$ is maintained on a constant level during successive captures, but the late summer and autumn generations $\left(G_{4}\right)$ show a tendency to decrease, although the material analysed is very small in this case, which may have been responsible for the results not being so accurate (Fig. 2). The size of the home range for females and males in 1972 in all generations and in all trapping series failed to vary in direction with successive captures (Fig. 2).

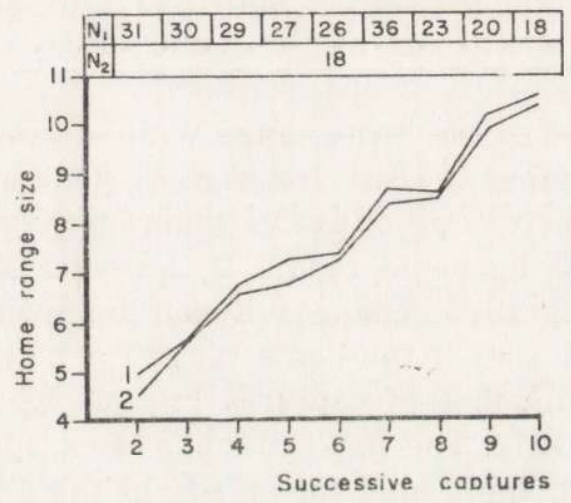

Fig. 3. Changes in average size of the home range of the overwinter generation (1) and selected males captured 10 or more times (2) in April 1967.

$N_{1}$ and $N_{2}$ numbers with a given number of captures of the first and second group.

The question then arises as to whether any increase in the size of the home range in successive trapping series does not result only from those individuals possessing a large home range continuing amongst those animals with a larger number of captures, since the more the number of captures of a given individual increases, the smaller is the number of individuals with a given number of captures (Fig. 3). This in turn means that if the average size of the home range at the second capture is estimated for a relatively large number of animals, this estimate at the tenth capture in the same generation applies to a smaller number of individuals. In order to check the correctness of this hypoth-

Fig. 2. Changes in size of the home range of males and females of different generations $\left(G_{0}-G_{4}\right)$ as successive captures take place.

Roman numerals indicate the months of trapping. 
esis, using old adult males from April 1967 as an example (i.e. the group of individuals for which the size of the home range increases intensively with successive captures), an examination was made of the size of the home range in successive captures from the second to the tenth, of course only in relation to those individuals which had been caught 10 or more times. This group was therefore composed only of the same individuals in the given period of captures. It was found that any increase in the size of the home range for this selected group does not differ from the increase in the size of the home range estimated for the whole generation of males during the same period (Fig. 3).

Thus during the period of additional feeding of these animals the size of the home range was observed to be stabilized during successive captures, whilst when the population subsisted only on the natural food supply an increase in the size of the home range was characteristic in the majority of cases.

Changes in the size of the home range with successive captures caused difficulty in determining the size for a given generation during a given trapping series, as there is no objective criterion giving the characteristic value of the size of the home range. If, however, comparison is made of curves illustrating these changes it can be seen that in the great majority of cases the size of the home range for both females and males estimated for each number of captures in 1967 were greater than the analogical values in 1973. The small number of exceptions (4 out of 24 of the curves examined) apply only to the size of the home range estimated for the second capture (Fig. 2). Thus the number of trapping sites visited by voles during a period of increased food supply was smaller than during the period when the population only lived off the natural food supply.

A check was next made to see whether variations in the size of the home range of females, calculated for successive captures, occur in a similar way when the food supply is artificially increased. Females with open vaginas were assumed to be participating in reproduction. The numbers in these two groups of females were only sufficient for this purpose in the early summer generation of June and July in 1973. It was found that the size of the home range of infertile females did not change in direction during successive captures in June, whereas in July there was a slight tendency to decrease. The size of the home range of females taking part in reproduction exhibits a slight endency to increase in both the months examined. The size of the home range for each number of captures is respectively greater for infertile females than for those taking part in reproduction (Fig. 4).

In order to discover the way in which the size of the home range of different generations varies over the course of a year when the pop- 
ulation lives on a natural food supply and when it is supplementarily fed, an arbitrary choice was made of the size of the home range estimated at the sixth capture as characterizing, for comparative purposes, the home ranges of different generations at different times (Fig. 5).

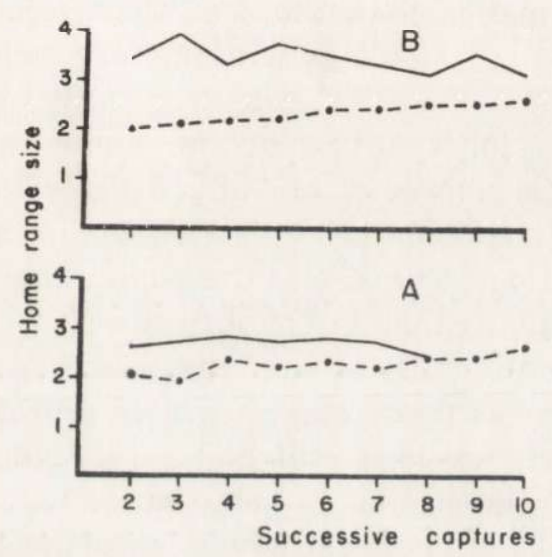

Fig. 4. Changes in average home range size of adult females (dotted line) and immature females (continuous line) of the spring generation as successive captures take place in the June $(A)$ and July $(B)$ trapping series.
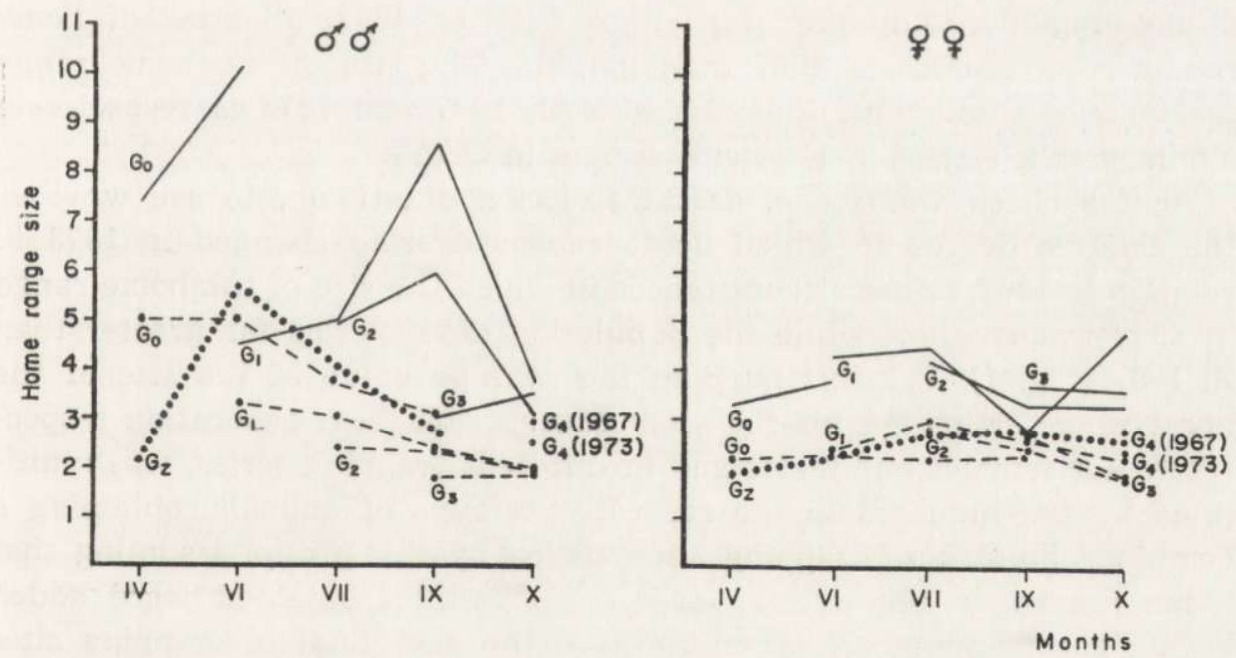

Fig. 5. Changes in average size of the home range of males and females over the course of a year.

Continuous line - 1967, dotted line $-1973, G_{z}-$ winter generation in 1973.

In 1967 the largest home ranges for males were found amongst the old adults, this size increasing still further from April to June (later the numbers of old adults are too small to permit an examination of the 
size of the home range). The spring and early summer generations had smaller home ranges than those of the old adults, although they increased more up to September in the case of the early summer generation. The late-summer and autumn generations had similar sizes of the home range, being smaller than those of the preceding generations. In October the home ranges of all generations are relatively small and of similar size.

In 1973 all values for the size of the home range of males were respectively smaller than those of 1967 . Each generation of males entering the population at a given time has a smaller home range than that of all the preceding generations. The size of the home range gradually decreases from this initial value, so that in October the size of the home range is similar for all generations. It is only the winter generation (which has no counterpart in 1967 as there was no winter reproduction) which behaves slightly differently, since it still had a relatively small home range in April, but in June the size of its home range was a little greater than that of overwintered animals, although subsequently the process of decrease in size of the home range takes a similar course to that in other generations (Fig. 5).

The size of the home range of females is not subject to any change in direction over the year for either 1967 or 1973 , all sizes of home range being greater in 1967 than in 1973. The size of the home range for females throughout the year in both 1967 and 1973 is respectively similar to the size of males' home ranges in October.

Next a check was made, as Bujalska did (1970), to see whether the relative degree to which home ranges overlap changed in 1973 in relation to 1967 , under circumstances in which the size of the home range in 1973 was smaller, while the population density was far greater than in 1967 (Fig. 1). For this purpose the average value of the size of the home range estimated for the sixth capture, for each generation respectively, for females and males and in different trapping series, was multiplied by the numbers in the respective groups of animals, obtaining a combined number of trapping sites visited by this group, assuming that home ranges do not overlap at all. The values obtained were added within the trapping series, which gave the sum total of trapping sites visited by the whole population. By dividing these sums by the number of trapping sites on the island the number of home ranges per trapping site during the different trapping series is obtained, assuming that the animals were evenly distributed over the island.

In 1967 the overlapping of the home range (for females and males) increased from spring to June from a value of 2 to a value of 4.8 , then decreased slightly to a value of 3.9 in October. In 1973 the average 
overlapping of home range in April was close to 6 in value, then increased to a value of 18.6 in July, and decreased to 16.4 in September and 11.4 in October. While a maximum average of 4.8 individuals visited each trapping site in 1967, in 1973 as many as 18.6 individuals visited each site (Fig. 6). If the size of the home range for September and October 1967 was accepted with the population numbers as for 1973, then the average overlapping of home ranges would increase respectively to the values of 32.7 and 20.8 individuals per trapping site.

These results show that decrease in the size of the home range in 1973 did not compensate for increase in spatial density of the population, expressed in the average number of overlapping home ranges on a trapping site. Spatial population density consequently decrease by only twice as much, whereas the chief part in its increase was played by an almost sixfold increase in population numbers (Fig. 1).

In turn calculation was made in the same way for the degree of overlapping of home ranges separately for males and females, and for

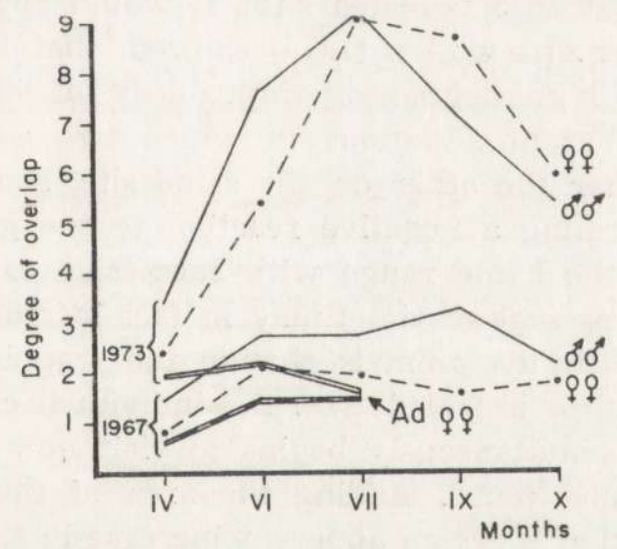

Fig. 6. Changes in degree to which home ranges overlap over the course of a year.

reproducing females. In 1967 the degree of overlapping of males' home ranges by far exceeds that of females for April, and particularly for June, while for July it is similar in both sexes and for September and October overlapping of females' home ranges exceeds that of males. The overlapping of home ranges for reproducing females in 1973 is far greater than for 1967 (Fig. 6).

\section{DISCUSSION}

Let us begin by accepting the basic assumptions of W ier $\mathrm{zbow}-$ $\mathrm{ska}$ 's (1972) estimate of the size of the home range that the home range has definite boundaries and hence that a definite number of trap- 
ping sites come within its boundaries. With these assumptions, the increase in the size of the home range found in the present studies with successive numbers of captures of the given group of individuals may be due to three causes:

1. The size of the home range may increase if correlation occurs between this value and the trappability of individuals. Attention has been drawn to this relation by Andrzejewski et al. (1967). The comparison made of the estimated size of the home range for successive captures in the group of individuals with constant group composition and in the group of individuals with varying composition (i.e. varying, as successive captures take place, on account of elimination of individuals with a small number of captures) showed that in the case examined the above hypothesis is not correct (Fig. 3).

2. The size of the home range may appear to increase, if the animals after being caught on a given trapping site avoid recapture on this site (i.e. probability of capture on a site not as yet revealed by an individual is greater than that on a revealed site). It would appear, as Andrzejewski \& Wierzbowska (1970) showed, that this hypothesis can be rejected. The high degree of trappability of individuals and the considerable number of situations in which two consecutive captures took place one after the other on the same site, show that it is not a question of elaborating a negative reaction to the given trapping site.

3 . The size of the home range with successive captures (and consequently with the passage of time) may in fact increase, or the situation may occur in which the animals change the trapping sites they visit as successive captures are made (i.e. the individual ceases to visit some of the sites, and simultaneously begins to visit new sites), shifting the location of its home range. Adding the area of these successive subhome ranges together gives an apparent increase in the size of the home range, since the number of any trapping sites visited does in fact increase with time.

It would, however, appear that these two possible interpretations of observed increase in the size of the home range can be rejected, since the trapping series were sufficiently brief to make it impossible during this time for intensive increase in the size of the home range to take place, or for changes in its location. M a zurkiewic z's studies (1971) carried out on the same material for 1967 also showed that the centres of the voles' activity alter their location on the island only very slightly from one trapping series to the next.

Calhoun \& Casby (1958), in giving the method for estimating the size of the home range for its circular shape, and also $\mathrm{Mazur}$ k 1 ewicz (1969) for the elliptical shape, accepted the assumption that 
the home range of small rodents has no defined boundaries, and the probability of catching a given individual decreases with increasing distance from the centre of its activity, in accordance with the normal two-dimensional distribution. If this is in fact so, then the application of Wierzbowska's method (1972) to such studies will show an increase in the size of the home range with successive capture (and consequently with the passage of time). This is a result of the way in which the animals move over their home ranges, in accordance with the assumptions of Calhoun \& Casby (1958) and Mazurkiewicz $(1969,1971)$, since with an increasing number of captures an increasingly large number of sites at a considerable distance from the centre of the home range are revealed. The rate of increase in the size of the home range with successive captures will depend on the intensity of the individual's movements over its home range (and consequently its trappability). The greater this penetration, the greater the probability that the individual will be caught within a given time further from the centre of its activity.

It would therefore undoubtedly seem that the correct hypothesis put forward by Calhoun and Casby and Mazurkiewicz gives, as the result of analysis of the home range by Wierzbowska's method, a picture of apparent increase in the size of the home range with successive captures. In the material studied this applies to the majority of generations at different periods of 1967 , when the population lived on the natural food supply.

An analogical analysis made during the year in which the voles were supplied with supplementary food (1973) gives, however, a different result. The size of the home range does not change with successive captures. This means that the way in which the animals move over the area during the year of supplementary feeding is not in agreement with the model given by Calhoun, Casby and Mazurkiewicz, but more with Wierzbowska's model: the animals visit a given constant number of trapping sites within a short interval of time (i.e. the duration of a trapping series).

Mathematical interpretation of results, both in accordance with Calhoun, Casby's and Mazurkiewicz's model, and Wierzbowska's model, from a reflection of the way in which voles move over the area, due to their normal patterns of behaviour and the habitat situation. It would appear that wanderings over the area in search of food may consist of the animals' journeys to the places in which food occurs over long periods of time (in accordance with Wierzbowska's model) and journeys in search of new sources of food (in accordance with the model of Calhoun, Casby and Mazurkiewicz). It is obvious that with an unfavourable 
food situation journeys in search of food are of fundamental importance. With a favourable food situation, in the case of supplementary food supply, the range of the animals' penetration is mainly limited to visiting a fixed numbers of places. The cases observed of lack of increase in the size of the home range with successive captures, when the animals lived on the natural food supply in 1967, take place in autumn when the food situation in forest ecosystems of the temperate zone is most favourable (G ór ecki \& G ę b c z yńs ka, 1962; Grodzińs k i, 1961,1963 , and others). It is also possible that stabilization of the home range of old adult females observed in spring is connected with the occurrance of a sufficient amount of food in their home ranges, as suggested by Nikitina \& Merkova (1963).

The only group of animals which exhibits a slight tendency to increase the size of the their home range with successive captures are the females taking part in reproduction. It is therefore only this group of individuals which cannot satisfy their needs within a limited home range even with an increased food supply, and undertake short journeys in search of food.

A result of providing supplementary food was that population numbers (density) was far higher in 1973 than in 1967 (Andrzejewski, 1974). The hypothesis may therefore be put forward that the difference in the way in which home ranges are used by voles is primarily the result of increase in density, and not of changes in food supply. An argument in favour of the above food hypothesis is, however, the fact that despite the very stabilized population numbers in 1967, the rate of change in take size of the home range estimated for successive captures changes considerably. In 1973, on the other hand, despite the fact that differences in density are very considerable (from 314 to 1079 individuals living on the island) stabilization of the size of the home range occurs independently of these changes (Fig. 2), and therefore in both years there is no relation between the degree of stabilization of the home range an the population density.

The different way in which the area is penetrated depending on the food situation in which the population finds itself does not permit of unequivocal definition of the range of penetration by different groups of animals, since both the methods discussed above fail to comply with their premises in one or other of the extreme food stituations. It would, however, appear that in order to give a relative description of the changes in the range of penetration (i.e. home range), Wier $\mathrm{zbow}-$ $\mathrm{sk}$ a's method (1972) is adequate if we accept a given number of captures for all the situations in which the size of the home range is estimated. 
The studies presented show (in agreement with numerous observations made by other authors) that the range of penetration of the area by males is greater than that of females. As the food situation is uniform for both sexes, the differences almost certainly result from extratrophic (i.e. sexual) behaviour of the animals. The social limitations of the range of penetration, revealing an increasingly small home range for generations entering the population in turn over during the course of the year (Mazurkiewicz, 1971) with an abundant food supply, are maintained in males. In females living on the natural food supply these limitations, occurring to a less intensive degree than in males, cannot be observed under conditions of an abundant food supply. It may therefore be assumed that the basis of social limitation of the size of the home range for the young generations does not (or not only) consist in food relations, while in females the food factor is of greater importance.

It is generally accepted that spatial relations in a population and density are the chief factors determining intensity of contacts between individuals in a population. As intensive increase in numbers (A $\mathrm{ndr} z \mathrm{e}-$ je wski, 1974) and decrease in the size of the home range took place, in the study population of voles, due to increasing the food supply, the question arises as to whether these two phenomena were capable of compensating for intensification of contacts in the population. There is as yet no method for examining frequency of contacts in a rodent population under forest conditions, but it may be assumed that frequency of contacts in a population is in proportion to the average number of individuals visiting each trapping site. This number is of course in direct proportion to population density and in inverse proportion to the size of the home range. The analysis made showed that the average number of individuals visiting one trapping site, greatly increased in 1973 as a result of a sixfold increase in numbers, was not compensated for by the relative reduction in the size of the home range, although this reduction reduced the number of individuals visiting one trapping site by half in relation to the value arising from the increase in density. This phenomenon has a similar character, if possible contacts between males only, between females only and also between females taking part in reproduction, are taken into account. The assumption may be reached from the foregoing that the food factor plays a more important part, in stimulating increase in numbers, than the spatial-social factors, in limiting these numbers.

Acknowledgements: Numerical elaboration of results in this study were made in the Statistics and Model Section of the Institute of Ecology, Polish Academy of Sciences. The authors wish to express their gratitude to Dr. T. Wierzbows k a and Dr. A. W a silewski for their critical reading of the text of this study and 
for their numerous and helpful remarks, and Dr. R. Kowalski for revising the English text.

\section{REFERENCES}

1. Andrzejewski R., 1975: Supplementary food and the winter dynamics of bank vole population. Acta theriol., 20: 23-40.

2. Andrzejewski R., PetrusewiczK. \& Waszkiewicz-GliwiczJ., 1967: The trappability of Clethrionomys glareolus (S chreber 1780) and other ecological parameters obtained by the CMR capture method. Ekol. pol., 15: $709-725$.

3. Andrzejewski R. \& Wierzbowska T. 1970: Estimate of the number of traps visited by small mammals based on a probabilistic model. Acta theriol., 15: 1-14.

4. Bujalska G., 1970: Reproduction stabilizing elements in an island population of Clethrionomys glareolus ( $\mathrm{S} \mathrm{chreber}, 1780$ ). Acta theriol., 15: 381-421.

5. Bujalska G., Andrzejewski R. \& Petrusewicz K. 1968: Productivity of an island population of Clethrionomys glareolus (S c h re be r, 178)). II. Natality. Acta theriol., 13: 415-425.

6. Calhoun J. B. \& Casby J. U., 1958: Calculation of home range and density of small mammals. U. S. Public Health Monogr., 55: 24.

7. Gliwicz J., 1970: Relation between trappability and age of individuals in a population of the bank vole. Acta theriol., 15: 15-23.

8. Gliwicz J., Andrzejewski R., Bujalska G. \& Petrusewicz ., 1968: Productivity investigation of an island population of Clethrionomys giareolus ( $\mathrm{Schreber}, 1780$ ). I. Dynamics of cohorts. Acta theriol., 13: 401-413.

9. Górecki A. \& G ęb c z ynska Z., 1962: Food conditions for small rodents in a deciduous forest. Acta theriol., 6: 275-295.

10. Grodziński W. 1961: Metabolism rate and bioenergetics of small rodents from the deciduous forest. Bull. Acad. Pol. Sci. Cl. II, 9: 493-499.

11. Grodziński W., 1963: Can food control the numbers of small rodents in the deciduous forest. Proc. XVI intern. Congr. Zool., 1: 257-258. Washington.

12. Ka raseva E. V. \& Ilyenko A. J., 1957: Nekotorye osobennosti biologii polevki-ekonomki, izučennye metodom mečenija zverkov. Fauna i Ekol. gryz., 5: $12-19$.

13. Lavrova M. Ja. \& Andreeva D. A. 1960: Polevki kak glavnye i vtorostepennye nositeli leptospir (po dannym nabludenij za mečenymi zverkani). Zool. Żurn., 39: 608-616.

14. M a z u rkiewicz M., 1969: Elliptical modification of the home range pattern. Bull. Acad. Pol. Sci. Cl. II, 17: 427-431.

15. Mazurkiewicz M., 1971: Shape, size and distribution of home ranges of Clethrionomys glareolus (S chreber, 1780). Acta theriol., 16: 23-60.

16. $\mathrm{M} \mathrm{cN}$ a b B. K., 1963: Bioenergetics and the determination of home range size. Am. Natur., 47: 133-140.

17. Nikitina N. A. \& Merkova M. A. 1963: Ispolzovanie territorii myšani i polevkami po dannym mečenija. Biull. mosk. Obšc. Ispyt. Prir., 68: 15-21

18. Petrusewicz K., Bujalska G., Andrzejewski R. \& Gliwicz J., 1971: Productivity processes in an island population of Clethrionomys glareolis. Ann. Zool. Fennici, 8: 127-132.

19. Saint-Girons M. Ch., 1960: Espace vital et comportement territorial chez Apodemus sylvaticus, Clethrionomys glareolus et Microtus agrestis. Relation avec les populations cycliques. Vie et Milieu, 11: 233-260. 
20. Smith M. H. 1971: Food as a limiting factor in the population ecology of Peromyscus polionotus (Wagner). Ann. zool. Fennici, 8: 109-112.

21. Traczyk H., 1965: The vegetation of "The Wild Apple-Tree Island " on the Lake Bełdańskie (North-eastern Poland). Fragm. flor. geobot., 11: 541-545.

22. Wierzbowska T., 1972: Statistical estimation of home range size of small rodents. Ekol. pol., 20: $781-831$.

23. Wierzbowska T. \& Chelkowska H., 1970: Estimating size of home range of 4 podemus agrarius (Pall.). Ecol. pol., 18: 1-12.

Accepted, October 23, 1975.

Roman ANDRZEJEWSKI i Maria MAZURKIEWICZ

\section{ZASOBNOSĆ BAZY POKARMOWEJ A WIELKOSĆ AREAEU NORNICY RUDEJ}

\section{Streszczenie}

Porównano wielkość areału samców i samic w różnym wieku w populacji nornicy, Clethrionomys glareolus ( $\mathrm{Schreber}, 1780$ ) w sytuacji, gdy populacja żywiła się naturalną bazą pokarmową (rok 1967) i gdy bazę tę zwiększono (rok 1973) przez stałe dokarmianie zwierząt owsem. Populacja zamieszkiwała wyspę o powierzchni 4 ha, porośniętą lasem. Rejestrację parametró́w populacji prowadzono metodą CMR, a wielkość areałów oceniano metodą Wierzbowskiej (1972). W 1967 r. wielkość areału samic i samców rośnie w miarę kolejnych złowień osobników, natomiast $\mathrm{w}$ roku $\mathrm{z}$ dodatkowym pokarmem areały $\mathrm{w}$ miarę kolejnych złowień zachowują stałą wielkość, przy czym są one mniejsze niż w roku 1967 (Ryc. 2). Zwiększanie się areału w kolejnych złowieniach w 1967 r. nie wynika z pozostawania wśród osobników o większej liczbie złowień jedynie takich, które posiadają duży areał (Rys. 3). Wchodzące do populacji kolejne pokolenia mają mniejsze areały od pokoleń starszych zarówno przy naturalnej bazie pokarmowej jak i w czasie jej zwiększenia (Rys. 5). Zmniejszenie się średniej wielkcści areałów w 1973 r. (Rys. 5) nie skompensowało wzrost stopnia nakrywania się areałów (Rys. 6) związanego ze wzrostem zagęszczenia populacji (Rys. 1).

W dyskusji próbuje się zinterpretować zmniejszenie oraz stabilizację wielkości areału osobniczego $\mathrm{w}$ warunkach eksperymentalnego zwiększenia bazy pokarmowej ograniczeniem penetracji terenu przez osobniki na dalszych odległościach od ich centrum aktywności. 